\title{
KEBERADAAN UANG PESANGON DALAM PEMUTUSAN HUBUNGAN KERJA DEMI HUKUM DI PERUSAHAAN YANG SUDAH MENYELENGGARAKAN PROGRAM JAMINAN PENSIUN
}

Oleh:

Ari Hernawan ${ }^{1}$

Fakultas Hukum Universitas Gadjah Mada

\begin{abstract}
Abstrak
Penelitian ini mengkaji keberadaan uang pesangon dalam pemutusan hubungan kerja demi hukum di perusahaan yang sudah menyelenggarakan program jaminan pensiun dan SK Direksi sebagai dasar pengaturannya. Penelitian ini bersifat normatif dengan data sekunder sebagai sumber data utama. Data dianalisis secara kualitatif dan disajikan secara deskriptif. Keberadaan uang pesangon disamakan dengan jaminan pensiun yang preminya dibayar penuh oleh pengusaha, dengan catatan besarannya tidak boleh lebih kecil dari uang pesangon yang seharusnya diterima buruh ketika memasuki usia pensiun. Kehadiran program asuransi pensiun tidak secara otomatis meniadakan pesangon yang harus diterima oleh para pekerja saat memasuki usia pensiun. SK Direksi tidak dapat dijadikan sebagai dasar pengaturan, karena dilihat dari segi proses pembuatan, isi dan sifatnya, bukan merupakan peraturan perusahaan.
\end{abstract}

Kata kunci : Pesangon, Pemutusan Hubungan Kerja, Jaminan Pensiun

Abstract

This research studies the presence of severance pay in employment termination by law in companies that have arranged pension security program and Board of Directors Decision as the legal bases. This research is a normative research with secondary data as its main data source. The data is analyzed qualitatively and presented descriptively. The presence of severance pay is equalized with pension security which premium is paid in full by business actors, with a note that the amount cannot be smaller than the severance pay payable to labors when they enter retirement period. Hence the presence of pension security program does not automatically nullify severance must be received by the workers when entering retirement period. Board of Directors Decision cannot be treated as regulation bases since seen from its drafting process, content and nature, it is not considered as the company regulation.

Keywords: Severance Pay, Termination of Employment, Pension Security

\section{Pendahuluan}

Hubungan buruh dan pengusaha rentan dengan permasalahan, salah satunya adalah Pemutusan Hubungan Kerja (PHK). PHK merupakan isu sensitif bagi buruh dan pengusaha mengingat implikasi yang ditimbulkan. Perselisihan PHK yang paling banyak terjadi selama ini adalah tindakan PHK yang dilakukan oleh salah satu pihak dan pihak lain tidak dapat menerimanya. ${ }^{2}$

Bagi buruh, pengenaan PHK akan menghilangkan mata pencaharian yang bukan hanya berpengaruh terhadap buruh yang bersangkutan, tetapi juga keluarganya, apalagi jika yang bersangkutan merupakan satu-satunya tulang punggung keluarga. Sulitnya mencari pekerjaan baru, menimbulkan situasi yang tidak enak karena harus menganggur, berkurangnnya harga diri

\footnotetext{
1 Ari Hernawan adalah seorang Guru Besar di Fakultas Hukum Universitas Gadjah Mada yang memiliki ketertarikan dalam menulis di bidang Hukum Perburuhan.

${ }^{2}$ Lalu Husni. 2005. Penyelesaian Perselisihan Hubungan Industrial Melalui Pengadilan dan di Luar Pengadilan. Jakarta : Penerbit RajaGrafindo Persada, h.46.
} 
KERTHA PATRIKA

Volume 38, Nomor 1, Januari-April 2016

apalagi jika selama ini memangku suatu jabatan, serta putusnya hubungan dengan teman-teman sekerja merupakan implikasi negatif terhadap buruh.

Bagi pengusaha, PHK menimbulkan kewajiban untuk memberikan kompensasi PHK bagi buruh. Semakin banyak buruh yang di-PHK dan semakin tinggi masa kerja buruh, maka semakin tinggi pula biaya kompensasi yang harus disiapkan oleh pengusaha. Sebagai gambaran, besaran uang pesangon yang harus dibayar pengusaha kepada buruh yang di-PHK di Indonesia tercatat tertinggi di-Asia. ${ }^{3}$ Risiko lain yang muncul bagi pengusaha akibat PHK adalah harus melepas buruh yang berpengalaman, mencari pengganti yang belum tentu hasilnya lebih baik dan biaya rekrutmen yang tidak sedikit. ${ }^{4}$

Mengingat besarnya implikasi tersebut, PHK merupakan upaya terakhir setelah upaya lain tidak berhasil dilakukan untuk menghindarinya. Untuk itu maksud melakukan PHK wajib dirundingkan oleh pengusaha dengan Serikat Buruh atau dengan buruh. Permasalahan akan terjadi apabila buruh yang bersangkutan tidak menjadi anggota Serikat Buruh. Dalam hal perundingan tidak menghasilkan kesepakatan, PHK hanya dapat dilakukan setelah memperoleh penetapan dari lembaga penyelesaian perselisihan hubungan industrial.

Menurut Pasal 152 Undang-Undang Nomor 13 Tahun 2003 tentang Ketenagakerjaan (UU Ketenagakerjaan), permohonan penetapan PHK diajukan secara tertulis kepada lembaga penyelesaian perselisihan hubungan industrial disertai alasan yang menjadi dasarnya. Permohonan tersebut dapat diterima apabila maksud PHK sudah dirundingkan. Penetapan atas permohonan PHK hanya dapat diberikan oleh lembaga penyelesaian hubungan industrial jika ternyata maksud untuk memutuskan hubungan kerja telah dirundingkan tetapi perundingan tersebut tidak menghasilkan kesepakatan.

Pasal 155 UU Ketenagakerjaan menentukan bahwa PHK tanpa penetapan batal demi hukum. Selama putusan lembaga penyelesaian perselisihan hubungan industrial belum ditetapkan, baik pengusaha maupun buruh harus tetap melaksanakan kewajibannya. Selama masih dalam proses PHK, pengusaha dapat melakukan skorsing terhadap buruh, dengan tetap wajib membayar upah buruh dan hak-hak lain yang biasa diterima buruh.

Penetapan lembaga penyelesaian perselisihan hubungan industrial tidak diperlukan dalam hal: buruh masih dalam masa percobaan; bila telah dipersyaratkan sebelumnya; buruh mengajukan permintaan pengunduran diri secara tertulis tanpa intimidasi dari pengusaha; hubungan kerja berakhir sesuai dengan perjanjian kerja waktu tertentu untuk pertama kali; buruh mencapai usia pensiun sesuai dengan ketetapan dalam perjanjian kerja, peraturan perusahaan, perjanjian kerja bersama atau peraturan perundangan; atau buruh meninggal dunia.

Dalam hal terjadi PHK pengusaha diwajibkan membayar uang pesangon dan/atau uang penghargaan masa kerja dan uang penggantian hak yang seharusnya diterima. Komponen upah yang digunakan sebagai dasar perhitungan uang pesangon, uang penghargaan masa kerja dan uang penggantian hak yang seharusnya diterima terdiri dari upah pokok dan segala macam bentuk tunjangan yang bersifat tetap yang diberikan kepada buruh dan keluarganya. Selain upah, besaran uang pesangon dan uang penghargaan masa kerja juga ditentukan oleh masa kerja.

${ }^{3}$ Muhtar Habibi. 2009.Gemuruh Buruh di Tengah Pusaran Neoliberalisme: Pengadopsian Kebijakan Perburuhan Neoliberal Pasca Orde Baru. Yogyakarta: Penerbit Gava Media, h. 64.

${ }^{4}$ Sedarmayanti. 2011.Manajemen Sumber Daya Manusia. Bandung: Penerbit Refika Aditama, h.313. 
Pasal 167 ayat (1) UU Ketenagakerjaan, selain PHK dari pengusaha dan PHK oleh buruh yang dikenal dengan pengunduran diri, juga dikenal PHK demi hukum yaitu PHK karena buruh memasuki usia pensiun. PHK karena buruh memasuki usia pensiun menjadi menarik untuk dicermati karena dalam perusahaan dimungkinkan hadirnya program jaminan pensiun.

Perusahaan yang sudah menyelenggarakan program jaminan pensiun merasa keberatan ketika masih diharuskan memberikan uang pesangon kepada buruh yang memasuki usia pensiun. Di sisi lain, ketika uang pesangon tidak dibayarkan kepada buruh yang memasuki usia pensiun dengan alasan sudah ada jaminan pensiun, buruh merasa keberatan. Bagi buruh, uang pesangon karena pensiun dan jaminan pensiun tidak dapat dipersamakan, apalagi jika dalam praktek buruh juga ikut membayar premi atau iuran jaminan pensiun dan besarnya jaminan atau manfaat pensiun yang diterima ternyata lebih kecil dari jumlah uang pesangon yang seharusnya diterima oleh buruh yang mengalami PHK karena memasuki usia pensiun. Bagi buruh, uang pesangon adalah kewajiban pengusaha dan hak buruh yang ter-PHK, sementara dalam jaminan pensiun buruh dimungkinkan masih harus menanggung iuran meskipun berbagi dengan pengusaha.

Secara praktek, perusahaan berbentuk Perseroan Terbatas yang sudah menyelenggarakan program jaminan pensiun, mengatur mengenai kehadiran uang pesangon dalam kebijakan internal perusahaan seperti yang berbentuk Surat Keputusan Direksi (SK Direksi). UU Ketenagakerjaan memang memberikan peluang untuk mengatur hal lain mengenai uang pesangon di perusahaan yang menyelenggarakan program jaminan pensiun, dalam perjanjian kerja, peraturan perusahaan atau perjanjian kerja bersama. Keberadaan SK Direksi oleh perusahaan dianggap sebagai peraturan perusahaan yang harus ditaati oleh buruh.

Pada umumnya perselisihan PHK terjadi akibat pertentangan pendapat terhadap dua hal yaitu mengenai sah tidaknya PHK dan atau besarnya uang pesangon. ${ }^{5}$ Keberadaan uang pesangon dalam perusahaan yang sudah menyelenggarakan program jaminan pensiun saat ini sudah menimbulkan persoalan di beberapa daerah di Indonesia. Setidaknya di Daerah Istimewa Yogyakarta, persoalan uang pesangon terkait program jaminan pensiun saat ini menjadi salah satu isu aktual perdebatan yang sedang ditangani Mediator Ketenagakerjaan.

Sebagai salah satu ilustrasi untuk mengkonstruksikan hal tersebut adalah persoalan di P.T. "X" yang sejak ditetapkan UU Ketenagakerjaan, belum memberikan hak normatif kepada pekerja yang telah diputus hubungan kerjanya karena memasuki usia pensiun berupa uang pesangon, uang penghargaan masa kerja, dan uang penggantian hak. P.T. "X" telah mengeluarkan SK Direksi pada tanggal 10 Oktober 2012 yang mengatur mengenai penyelesaian kewajiban perusahaan terhadap pekerja yang berakhir hubungan kerjanya karena mencapai usia pensiun normal, yaitu 56 tahun. SK Direksi tersebut telah menimbulkan permasalahan karena mengakibatkan lebih dari $85 \%$ para pensiunan P.T. "X" tidak menerima pesangon sama sekali.

P.T. "X" telah mengikutsertakan para pekerjanya dalam program tabungan dana pensiun yang iurannya dibayarkan oleh perusahaan dan pekerja dengan beban pembagian $72 \%$ beban perusahaan dan $28 \%$ beban pekerja yang dipotong dari gaji selama bekerja. Para pekerja di P.T. "X" diikutkan dalam 2 program dana pensiun yaitu program pensiun manfaat pasti yang dikelola oleh lembaga dana pensiun P.T. "X" dan program pensiun iuran pasti yang dikelola oleh dana pensiun lembaga keuangan.

\footnotetext{
${ }^{5}$ Sehat Damanik. 2007. Hukum Acara Perburuhan. Jakarta: Penerbit Dss Publishing, h. 24.

${ }^{6}$ Data ada di penulis.
} 
KERTHA PATRIKA

Volume 38, Nomor 1, Januari-April 2016

Terdapat perbedaan ketentuan pesangon yang diatur dalam UU Ketenagakerjaan dengan SK Direksi P.T. "X” tersebut. Dalam Pasal 156 ayat (4) UU Ketenagakerjaan, uang penggantian hak yang persentasenya ditetapkan $15 \%$ adalah penggantian perumahan serta pengobatan dan perawatan dari uang pesangon dan/atau uang penghargaan masa kerja bagi yang memenuhi syarat, sedangkan dalam SK Direksi P.T. "X" penggantian hak ditetapkan $15 \%$ dari besarnya uang pesangon dan uang penghargaan masa kerja yang diperhitungkan sebagai pesangon. Menurut Pasal 167 ayat (3) UU Ketenagakerjaan, ketika pengusaha telah mengikutsertakan pekerja dalam program pensiun yang iuran/preminya dibayar oleh pengusaha dan pekerja, maka yang diperhitungkan dengan pesangon yaitu uang pensiun yang premi/iuran dibayar oleh pengusaha. SK Direksi P.T. "X" menekankan iuran pensiun yang merupakan beban perusahaan diperhitungkan sebagai pembanding uang pesangon, dengan ketentuan apabila dalam pembayaran iuran pensiun oleh perusahaan, berdasarkan data dari Program Pensiun Manfaat Pasti dan Program Pensiun Iuran Pasti terdapat kelebihan atau sama dengan uang pesangon, maka perusahaan tidak akan memberikan pesangon. Dalam situasi berbeda, jika iuran pensiun dari perusahaan lebih kecil setelah dibandingkan dengan uang pesangon, maka perusahaan akan membayarkan kekurangannya dan dianggap sebagai pesangon. Perbedaan pengaturan mengenai pesangon di perusahaan yang sudah menyelenggarakan program jaminan pensiun antara UU Ketenagakerjaan dan SK Direksi ini membawa persoalan mengenai keberadaan uang pesangon dan perbedaan perhitungan mengenai besaran pesangon diterima oleh pekerja.

Hal yang menjadi persoalan adalah pengaturan mengenai uang pesangon di perusahaan yang menyelenggarakan jaminan pensiun sangat minim. Hanya ada satu pasal di dalam UU Ketenagakerjaan, sehingga memerlukan analisis yang mendalam melalui penelitian. Kehadiran jaminan pensiun juga baru diakomodasikan dalam Undang-Undang Nomor 40 tahun 2004 tentang Sistem Jaminan Sosial Nasional (UU SJSN). Dalam Undang-Undang Jaminan Sosial Tenaga Kerja sebelumnya lembaga ini belum hadir. Kehadiran pengaturan uang pesangon di perusahaan yang menyelenggarakan program jaminan pensiun seolah-olah dipaksakan dan menguatkan dugaan bahwa sistem jaminan sosial nasional di Indonesia merupakan bentuk sistem hukum perburuhan yang mendukung efisiensi ekonomi dengan antara lain mengurangi ongkos melalui pasar buruh yang fleksibel salah satunya dalam kompensasi PHK.

Menurut Pasal 39 UU SJSN, jaminan pensiun diselenggarakan untuk mempertahankan derajat kehidupan yang layak pada saat peserta kehilangan atau berkurang penghasilannya karena memasuki usia pensiun atau mengalami cacat total tetap. Jaminan pensiun merupakan salah satu bentuk perlindungan untuk menjamin agar buruh dapat memenuhi kebutuhan dasarnya secara layak meskipun sudah memasuki masa pensiun. ${ }^{7}$ Jaminan pensiun dengan demikian merupakan kebijakan untuk memberikan tunjangan pendapatan (income support) karena situasi yang mendesak maupun situasi yang sudah diperkirakan sebelumnya (life circle).

Jaminan pensiun di Indonesia dikelola dalam bentuk asuransi sosial yang merupakan sistem asuransi individual berkaitan dengan pendapatan. Jaminan ini dibayarkan setelah si penerima pensiun dari tempatnya bekerja dan biasanya ada waktu bekerja minimum bagi buruh un-

${ }^{7}$ Muhammad Aditya Warman. 2013. Social Security and Minimum Wages in Indonesia. Jakarta: Penerbit Pusat Studi Apindo, h. 107. 
tuk dapat menerima manfaat jaminan pensiun ini. ${ }^{8}$ Jaminan pensiun dibayarkan melalui sistem pay-as-you-go. Jumlah uang yang diterima sebagai manfaat program ini sebanyak persentase tertentu dari jumlah rata-rata penghasilan buruh. ${ }^{9}$

Secara umum, kontribusi terhadap skim jaminan pensiun dapat berasal dari berbagai pihak (payroll contributions) yaitu pemerintah, buruh dan pengusaha dan karena itu masih minimalis karena hanya diberikan kepada PNS dan swasta yang mampu membayar iuran ${ }^{10}$. Persoalan jaminan sosial termasuk jaminan pensiun dengan demikian memiliki kompleksitas, karena tidak hanya terkait dengan keuangan dan kepesertaan, tetapi juga melibatkan infrastruktur, kelembagaan dan pengaturan.

Saat ini, sejalan dengan rekomendasi International Labour Organization (ILO) agar sistem jaminan sosial nasional memperluas cakupannya, jaminan pensiun mencakup buruh formal maupun informal. ${ }^{11}$ Dengan demikian apa yang dikemukakan oleh John Naisbitt seorang futurolog terkenal bahwa dunia abad 21 adalah milik Asia karena kawasan ini tidak memiliki beban sebagai negara kesejahteraan dengan menyelenggarakan program jaminan sosial bagi warga negaranya dan oleh karena itu tidak memiliki beban ekonomi dan bisa berkonsentrasi pada persoalan pembangunan ekonomi, menjadi terbantahkan karena arti penting jaminan sosial semakin disadari. ${ }^{12}$

Walaupun demikian apa yang dikemukakan Naisbitt tersebut masih relevan karena muncul persoalan, apakah penyelenggaraan jaminan sosial akan menghambat pembangunan ekonomi negara jika kekurangan modal dan terlalu besar jumlah penduduknya. Di tingkat perusahaan, hal tersebut juga dapat memicu penyimpangan di fase implementasi hukumnya.

Terjadinya transformasi dalam rezim Hukum Perburuhan Indonesia, dari semacam model hukum perburuhan yang korporatis dengan sebuah negara yang kuat di belakangnya menjadi lebih berbasis pasar yang menghasilkan semacam hubungan perburuhan baru yang ditandai makin lemahnya posisi buruh terhadap pemodal dan makin kuatnya posisi tawar pemodal terhadap negara dapat saja mempengaruhi bekerjanya hukum perburuhan termasuk jaminan pensiun di dalamnya. Negara cenderung berusaha memenuhi sebagian besar keinginan pemodal dengan memberikan fasilitas berupa regulasi yang permisif bagi pemodal atau melakukan pembiaran penyimpangan peraturan yang dibuat sendiri. ${ }^{13}$

Berdasarkan latar belakang di atas dapat dirumuskan permasalahan sebagai berikut:

1. Apakah kehadiran program jaminan pensiun yang diselenggarakan oleh perusahaan dapat

\footnotetext{
${ }^{8}$ Michael Raper. 2008. Negara Tanpa Jaminan Sosial. Jakarta: Penerbit TURC, h. 18.

9 Alex Arifianto."Perbaikan Sistem Jaminan Sosial di Indonesia, Sebuah Analisis tentang RUU Jaminan Sosial Nasional”, Hasil Riset, Jakarta: SMERU Institute Research, September 2004.

${ }^{10}$ Roni Febrianto, “Jaminan Sosial, Haruskah Rakyat Menunggu?”, Artikel dalam Jurnal Kajian Perburuhan SEDANE, Vol. 11, No. 1, 2011, h. 41-42.

${ }^{11}$ International Labour Organization, "Social Security and Coverage For All”, Paper, Jakarta: International Labour Office, Desember 2002.

${ }^{12}$ Tapi Omas Ihrom. 2006.“Sistem Jaminan Sosial Indonesia dalam Perubahan”, Artikel dalam Buku Makin Terang Bagi Kami Belajar Hukum Perburuhan. Jakarta: Penerbit TURC, h. 196-200.

${ }^{13}$ Surya Tjandra dan Rani Hanggrahini. 2007. Hukum Perburuhan, Desentralisasi dan Rekonstitusi Rezim Perburuhan, Jakarta: Penerbit TURC, h. 29
} 


\section{KERTHA PATRIKA}

Volume 38, Nomor 1, Januari-April 2016

meniadakan keberadaan uang pesangon yang seharusnya diterima oleh buruh ketika memasuki masa pensiun?

2. Bagaimana keberadaan SK Direksi yang dijadikan sebagai dasar hukum pengaturan uang pesangon dalam perusahaan yang menyelenggarakan program jaminan pensiun dari perspektif Hukum Perburuhan?

Tujuan dari penelitian ini adalah untuk mengembalikan hakekat uang pesangon dan jaminan pensiun sesuai dengan semangat kelahirannya, sebagai bentuk perlindungan sosial untuk membangun kehidupan ekonomi sosial yang lebih baik dan layak, bagi pensiunan. Penelitian ini juga bertujuan untuk menempatkan uang pesangon dan jaminan pensiun dalam sistem hukum perburuhan Indonesia, sehingga dapat menjadi pedoman bagi para pelaku hubugan industrial.

\section{Metode Penelitian}

Artikel ini merupakan penelitian hukum normatif yang mengandalkan data sekunder sebagai sumber data utama. Walaupun demikian, masih dibutuhkan data primer melalui penelitian lapangan untuk melengkapinya. Bekerjanya norma dalam praktek merupakan penguat dalam menganalisis norma yang ada dalam produk peraturan perundang-undangan. Penelitian ini juga dapat dikatakan besifat deskripif analitis. Dikatakan deskriptif karena menggambarkan permasalahan yang dibahas, berikut hasil penelitian dan pembahasan beserta jawaban atas permasalahan. Menggunakan analitis karena berbagai asas hukum, sistem hukum, dan peraturan hukumnya dianalisis untuk menjawab permasalahan yang diajukan dalam penelitian.

Penelitian kepustakaan dilakukan melalui berbagai bahan hukum. Bahan hukum dalam penelitian ini diperoleh dari bahan-bahan pustaka melalui perpustakaan, dokumen-dokumen, peraturan perundangan dan tulisan-tulisan lain yang berhubungan dengan permasalahan, yang terdapat antara lain di dalam bahan hukum primer dan bahan hukum sekunder. Cara yang dipergunakan adalah studi dokumen, yaitu studi dengan cara mempelajari data baik berupa buku, laporan hasil penelitian, makalah seminar, tulisan para ahli, dan peraturan yang berkaitan dengan materi penelitian.

Data yang dicari dalam penelitian lapangan adalah data primer dan merupakan data yang diperoleh secara langsung dari subyek penelitian. Permasalahan dalam penelitian ini sebenarnya tidak mengharuskan penunjukan wilayah tertentu mengingat karakternya, namun demikian dalam penelitian ini, penelitian lapangan dilakukan di Daerah Istimewa Yogyakarta. Subjek penelitian meliputi Ketua Aliansi Buruh Yogyakarta, Ketua Aliansi Pengusaha Indonesia Daerah Istimewa Yogyakarta dan Kepala Dinas Tenaga Kerja dan Transmigrasi Daerah Istimewa Yogyakarta yang dijadikan sebagai narasumber disamping buruh dan pengusaha P.T. "X" dan P.T. "Y" (data ada di penulis) serta mediator ketenagakerjaan sebagai responden. Adapun cara pengumpulan data dilakukan dengan cara wawancara tidak terstruktur dan alat yang digunakan adalah pedoman wawancara yang memuat hal-hal pokok atau garis besar materi wawancara. Data primer dan data sekunder yang diperoleh melalui penelitian dianalisis secara kualitatif, dan hasilnya disajikan secara deskriptif. 


\section{Hasil dan Pembahasan}

\section{Keberadaan Uang Pesangon dalam Pemutusan Hubungan Kerja Demi Hukum di Perusa- haan yang Sudah Menyelenggarakan Program Jaminan Pensiun}

PHK adalah pengakhiran hubungan kerja karena suatu hal tertentu yang mengakibatkan berakhirnya hubungan hak dan kewajiban antara buruh/pekerja dan pengusaha. PHK bisa dilakukan oleh pengusaha, pekerja/buruh atau demi hukum. Salah satu jenis PHK demi hukum adalah berakhirnya perjanjian kerja atau pekerja/buruh telah memasuki masa pensiun.

Pengusaha dapat melakukan PHK karena pekerja memasuki usia pensiun tanpa melalui proses PHK pada umumnya. Demikian juga dalam hal pemberian kompensasi, pekerja/buruh yang mengalami PHK demi hukum karena berakhirnya perjanjian kerja berhak atas dua kali ketentuan mengenai uang pesangon yang sudah diatur dalam UU Ketenagakerjaan, satu kali uang penghargaan masa kerja dan penggantian hak.

Keberadaan pesangon dalam PHK demi hukum karena berakhirnya perjanjian kerja ini mendapatkan pengecualian dari ketentuan UU dalam hal perusahaan sudah menyelenggarakan program jaminan pensiun. Apabila pengusaha telah mengikutsertakan pekerja pada program pensiun yang iurannya dibayar penuh oleh pengusaha maka pekerja tidak berhak atas uang pesangon dan uang penghargaan masa kerja, tetapi berhak atas uang penggantian hak. Dengan demikian untuk mengetahui uang pesangon dalam PHK demi hukum karena berakhirnya perjanjian kerja harus dilihat terlebih dahulu apakah perusahaan sudah menyelenggarakan program jaminan pensiun dan siapakah yang membayar premi/iurannya.

UU Ketenagakerjaan tidak memberikan pengertian tentang pensiun. Penafsiran otentik mengenai pensiun justru ditemukan dalam Undang-Undang Nomor 43 tahun 1999 tentang Kepegawaian (UU Kepegawaian) yang mendefinisikan pensiun sebagai jaminan hari tua dan balas jasa terhadap pegawai negeri yang telah bertahun-tahun mengabdikan dirinya kepada negara. UU Kepegawaian mempersamakan uang pensiun dengan jaminan hari tua.

Sulit mempersamakan definisi pensiun dalam Undang-Undang Kepegawaian dengan makna yang tersirat dalam pensiun menurut UU Ketenagakerjaan. Dalam UU Ketenagakerjaan jaminan hari tua adalah lembaga tersendiri yang keberadaannya dipisahkan dengan jaminan pensiun dan pesangon. Pasal 167 ayat (6) UU Ketenagakerjaan secara tegas menyatakan bahwa hak atas manfaat pensiun tidak menghilangkan hak pekerja/buruh atas jaminan hari tua yang bersifat wajib sesuai dengan peraturan perundangan yang berlaku. Konsep pensiun yang ada dalam Undang-Undang Kepegawaian memang hanya cocok diterapkan bagi pegawai negeri sipil, dan bukan bagi buruh/pekerja.

Jaminan hari tua menurut UU SJSN diselenggarakan berdasarkan prinsip asuransi sosial atau tabungan wajib. Jaminan hari tua diselenggarakan dengan tujuan untuk menjamin agar peserta menerima uang tunai apabila memasuki masa pensiun, mengalami cacat total tetap, atau meninggal dunia. Peserta jaminan hari tua adalah peserta yang telah membayar iuran.

Manfaat jaminan hari tua berupa uang tunai dibayarkan sekaligus pada saat peserta memasuki usia pensiun, meninggal dunia, atau mengalami cacat total tetap. Besarnya manfaat jaminan hari tua ditentukan berdasarkan seluruh akumulasi iuran yang telah disetorkan ditambah 
KERTHA PATRIKA

Volume 38, Nomor 1, Januari-April 2016

hasil pengembangannya. Pembayaran manfaat jaminan hari tua dapat diberikan sebagian sampai batas tertentu setelah kepesertaan mencapai minimal 10 tahun. Apabila peserta meninggal dunia, ahli warisnya yang sah berhak menerima manfaat jaminan hari tua.

Besarnya iuran jaminan hari tua untuk peserta penerima upah ditetapkan berdasarkan persentase tertentu yang ditanggung bersama oleh pemberi kerja dan bekerja. Besarnya iuran jaminan hari tua untuk peserta yang tidak menerima upah ditetapkan berdasarkan jumlah nilai nominal yang ditetapkan secara berkala oleh pemerintah. Dari hal-hal yang diutarakan di atas mengenai jaminan hari tua, dapat disimpulkan bahwa jaminan pensiun bukan jaminan hari tua.

SK Direksi yang dijadikan kajian dalam penelitian ini hanya menyebutkan "pensiunan" adalah pekerja yang bekerja di perusahaan tersebut yang berakhir hubungan kerjanya karena mencapai usia pensiun normal setelah diberlakukannya UU Ketenagakerjaan. Undang-undang ini tidak mengatur mengenai batas usia berlakunya hubungan kerja. Dengan demikian, ketentuan tentang batas usia pensiun ditetapkan dalam perjanjian kerja, peraturan perusahaan dan atau perjanjian kerja bersama atau peraturan perundangan yang terkait dengan masa pensiun. Mengenai batas usia pensiun dalam UU Ketenagakerjaan diserahkan kepada mekanisme hukum privat atas dasar kebebasan berkontrak.

Selanjutnya, UU SJSN hanya menyebutkan bahwa jaminan pensiun diselenggarakan secara nasional berdasarkan prinsip asuransi sosial atau tabungan wajib. Pada dasarnya mekanisme jaminan pensiun berdasarkan asuransi sosial, namun diberikan kesempatan kepada pekerja/ buruh yang memasuki usia pensiun tetapi masa iurannya tidak mencapai waktu yang ditentukan, untuk diberlakukan sebagai tabungan wajib dan dibayarkan pada saat yang bersangkutan berhenti bekerja, ditambah hasil pengembangannya.

Jaminan pensiun diselenggarakan untuk mempertahankan derajat kehidupan yang layak pada saat peserta kehilangan atau berkurang penghasilannya karena memasuki usia pensiun atau mengalami cacat total tetap. Hal tersebut berarti besaran jaminan pensiun harus mampu memenuhi kebutuhan pokok pekerja/buruh dan keluarganya. Jaminan pensiun diselenggarakan berdasarkan manfaat pasti, yaitu adanya batas minimum dan maksimum manfaat yang akan diterima peserta.

Manfaat jaminan pensiun berwujud uang tunai dibayarkan kepada peserta yang telah mencapai usia pensiun sesuai formula yang ditetapkan. Besarnya iuran jaminan pensiun untuk peserta penerima upah ditentukan berdasarkan persentase tertentu dari upah atau penghasilan atau suatu jumlah nominal tertentu, yang ditanggung bersama antara pemberi kerja dan pekerja. Dalam UU Ketenagakerjaan, iuran jaminan pensiun dapat dibayarkan penuh oleh pengusaha, yang disamakan dengan uang pesangon.

Konsep jaminan pensiun dalam UU SJSN lebih lengkap daripada konsep jaminan pensiun dalam UU Ketenagakerjaan dalam kaitannya dengan pesangon. Menurut UU SJSN, manfaat jaminan pensiun berwujud uang tunai yang dapat diterima bukan hanya sebagai pensiun hari tua yang diterima peserta setelah pensiun, tetapi dapat berupa pensiun cacat, pensiun duda/janda, pensiun anak, pensiun orang tua. Masing-masing manfaat pensiun tersebut sudah mendapatkan pengaturan yang mencukupi di UU SJSN.

Pengertian dana pensiun juga tidak dikenal dalam UU Ketenagakerjaan. UU SJSN bahkan tidak memberikan pengertian dana pensiun. Dalam UU SJSN hanya diakomodasikan mengenai 
dana jaminan sosial yang disebut sebagai dana amanat milik seluruh peserta yang merupakan himpunan seluruh iuran beserta hasil pengembangannya yang dikelola oleh Badan Penyelenggara Jaminan Sosial untuk pembayaran manfaat kepada peserta dan pembiayaan operasional penyelenggaraan program jaminan sosial.

Pengertian dana pensiun muncul dalam Undang-Undang Nomor 11 tahun 1992 tentang Dana Pensiun (UU Dana Pensiun) yang disebutkan berupa iuran pemberi kerja atau iuran pemberi kerja dan peserta. Menurut undang-undang tersebut, setiap pekerja yang memenuhi syarat kepesertaan dalam dana pensiun yang didirikan oleh pendiri kerja berhak atas manfaat pensiun. Manfaat pensiun diartikan sebagai pembayaran berkala yang dibayarkan kepada peserta pada saat dan dengan cara yang ditetapkan dalam peraturan dana pensiun. Manfaat pensiun adalah faedah jaminan pensiun yang menjadi hak peserta.

Dalam Pasal 167 ayat (3) UU Ketenagakerjaan disebutkan bahwa dalam hal besarnya jaminan atau manfaat pensiun yang diterima sekaligus dalam program pensiun ternyata lebih kecil dari jumlah pesangon dan penghargaan masa kerja serta uang penggantian hak, maka selisihnya harus dibayar oleh pengusaha. Berdasarkan ketentuan tersebut, jenis penerimaan uang pensiun ada dua yaitu uang manfaat pensiun yang diterima sekaligus dan uang manfaat pensiun yang diterima setiap bulannya. Dalam hal yang disebutkan terakhir, uang yang dipakai sebagai pembayaran pensiun atau dikenal sebagai dana pensiun dikelola oleh suatu badan hukum yang menjalankan program pensiun. Dengan demikian dana pensiun dalam hal ini adalah dana amanat milik seluruh peserta yang merupakan himpunan iuran beserta hasil pengembangannya yang dikelola oleh badan penyelenggara untuk pembayaran manfaat kepada peserta dan pembiayaan operasional penyelenggaraan program tersebut.

Ada dua dana pensiun yang berlaku menurut Undang-Undang Dana Pensiun yaitu pemberi kerja yang dibentuk dan dikelola oleh perusahaan pemberi kerja yang memberi program pensiun manfaat pasti dan iuran pasti bagi seluruh pekerjanya dan dana pensiun lembaga keuangan yang didirikan oleh bank atau perusahaan asuransi bagi masyarakat umum maupun pekerja dan pekerja mandiri.

Dalam SK Direksi P.T. "X” No. Kep : 883-DIR/KPS/10/2012 tentang Penyelesaian Kewajiban Perusahaan terhadap Pekerja yang Berakhir Hubungan Kerjanya karena Mencapai Usia Pensiun Normal sebagai Implementasi dari Undang-Undang Nomor 13 Tahun 2003 tentang Ketenagakerjaan dan SK Direksi P.T. "Y" No. Kep : 02243.K/1.2/II/2013 tentang Penetapan Manfaat Pensiun, yang dijadikan kajian dalam penelitian ini, dana pensiun yang diberikan kepada pekerja yang memasuki usia pensiun meliputi program manfaat pensiun pasti yang diperhitungkan dan dibayarkan oleh dana pensiun perusahaan yang bersangkutan, program pensiun iuran pasti, yang diperhitungkan dan dibayarkan oleh dana pensiun lembaga keuangan dan manfaat lain sesuai peraturan perundangan yang berlaku. Iuran program pensiun berupa program pensiun manfaat pasti dan program pensiun iuran pasti yang besarnya ditetapkan dalam peraturan dana pensiun dan pembayarannya dibebankan kepada perusahaan dan pekerja dengan pembagian 72 $\%$ menjadi beban perusahaan dan $28 \%$ menjadi beban pekerja untuk perusahaan " $X$ " dan $60 \%$ menjadi beban perusahaan serta $40 \%$ menjadi beban pekerja untuk perusahaan "Y".

Dalam SK Direksi tersebut juga diatur mengenai kompensasi pensiun yaitu selisih kurang dari uang pensiun yang diperhitungkan terhadap pesangon sehubungan dengan diberlakukannya 


\section{KERTHA PATRIKA}

Volume 38, Nomor 1, Januari-April 2016

UU Ketenagakerjaan. Uang kompensasi pensiun dibayarkan sekaligus kepada pekerja setelah pensiun karena perjanjian kerja berakhir.

Dalam UU Ketenagakerjaan tidak diatur apakah yang dimaksud dengan pesangon. Secara umum dapat dikatakan bahwa pesangon adalah sejumlah uang yang wajib dibayarkan pengusaha kepada pekerja karena PHK, dengan catatan memenuhi kualifikasi tertentu, karena tidak semua PHK diikuti dengan pemberian pesangon. Uang pesangon selain dikaitkan dengan PHK, juga dikaitkan dengan kewajiban pengusaha. Pesangon tidak ada kaitan sama sekali dengan kewajiban buruh/pekerja dan keberadaannya muncul karena perintah undang-undang. Dengan demikian ada keterkaitan antara pesangon, PHK dan kewajiban pengusaha. Jumlah nominal uang pesangon, juga dipengaruhi upah dan masa kerja pekerja/buruh yang bersangkutan. Ini merupakan karakteristik pesangon yang membedakan dengan jaminan pensiun.

Secara tidak konsisten tiba-tiba muncul Pasal 167 UU Ketenagakerjaan terkait dengan keberadaan uang pesangon di perusahaan yang sudah menyelenggarakan program pensiun. Pesangon yang awalnya dikatakan merupakan kewajiban pengusaha, kemudian bergeser maknanya karena dalam perusahaan yang telah mengikutsertakan pekerja dalam program pensiun, tidak perlu memberi pesangon jika iuran atau preminya dibayarkan oleh pengusaha dan besarannya tidak lebih kecil dari pesangon. Dengan demikian iuran premi tidak hanya dari pemberi kerja tetapi dimungkinkan untuk berbagi dengan pekerja. Artinya secara filosofis sebenarnya pesangon berbeda dengan uang pensiun karena pesangon sudah pasti kewajiban pengusaha semata dan uang pensiun dilakukan dengan konsep asuransi yang mengenal adanya premi/iuran dan dimungkinkan bukan hanya menjadi kewajiban pengusaha tetapi bisa dibagi beban preminya dengan buruh/pekerja.

Hal tersebut dikuatkan dengan penjelasan Pasal 167 ayat (3) UU Ketenagakerjaan yang menyebutkan pesangon yang diterima pekerja meliputi manfaat pensiun yang diterima sekaligus yang iurannya dibayar oleh perusahaan, manfaat pensiun yang diterima sekaligus yang iurannya dibayar oleh pekerja dan selisih dari manfaat pensiun yang iurannya dibayarkan perusahaan setelah dikurangkan dari semua hak pekerja. SK Direksi yang dijadikan kajian dalam penelitian ini mengatur jika perhitungan uang pensiun sama dengan pesangon, maka tidak ada kewajiban perusahaan untuk membayar kompensasi pensiun. Jika perhitungan pensiun lebih besar daripada pesangon, maka tidak ada kewajiban perusahaan membayar kompensasi pensiun dan selisih kelebihan kompensasi pensiun akan diberikan kepada pensiunan atau tidak ada kewajiban untuk dikembalikan ke perusahaan oleh pensiunan. Dalam hal penghitungan pensiun lebih kecil daripada pesangon, maka ada kewajiban pembayaran perusahaan membayar selisih kekurangannya kepada pensiunan sebagai kompensasi pensiun berikut pengembangannya sesuai kebijakan perusahaan.

SK Direksi juga menentukan besarnya pesangon yang akan dibayarkan kepada pensiunan mendasarkan kepada hasil perbandingan antara pesangon dengan uang pensiun manfaat sekaligus. Apabila uang pensiun manfaat sekaligus yang menjadi beban perusahaan ternyata lebih kecil dari pesangon, maka perusahaan akan membayar kekurangannya tersebut, tetapi jika uang manfaat pensiun sekaligus yang menjadi beban perusahan ternyata lebih besar atau sama dengan pesangon maka perusahaan tidak akan membayar pesangon pada pekerjanya. Ini berbeda dengan perhitungan pensiun menurut Pasal 167 ayat (3) UU Ketenagakerjaan yang menentukan sebagai hasil penjumlahan 
iuran manfaat pensiun sekaligus yang menjadi beban perusahaan, manfaat pensiun sekaligus yang menjadi beban pekerja dan selisih kurang dari uang pensiun manfaat sekaligus yang menjadi beban perusahaan setelah dibandingkan dengan dua kali pesangon, uang penghargaan masa kerja dan uang penggantian hak. Inilah yang membedakan dengan SK Direksi yang mempersamakan pesangon dengan kompensasi pensiun saja, sehingga hasil sebagai akibat dari perbedaan tersebut pensiunan tidak mendapatkan pesangon.

Sebagai gambaran maksud dari Pasal 167 ayat (3) tersebut, misalnya uang pesangon yang seharusnya diterima pekerja/buruh adalah 10 juta rupiah dan besarnya jaminan pensiun menurut program pensiun adalah 6 juta rupiah serta dalam pengaturan program pensiun tersebut telah ditetapkan premi yang ditanggung pengusaha $60 \%$ dan oleh pekerja/buruh $40 \%$. Perhitungan uang yang harus diterima oleh buruh/pekerja adalah sebagai berikut :

a. Penghitungan hasil dari premi yang sudah dibayarkan oleh pengusaha adalah $60 \% \times 6$ juta $=$ Rp. 3.600.000,- (tiga juta enam ratus ribu rupiah).

b. Besarnya santunan yang preminya dibayar oleh pekerja/buruh adalah $40 \% \times 6$ juta $=\mathrm{Rp}$. 2.400.000,- (dua juta empat ratus ribu rupiah).

c. Kekurangan yang masih harus dibayar oleh pengusaha sebesar 10 juta dikurangi $\mathrm{Rp}$. 3.600.000,- (tiga juta enam ratus ribu rupiah) menjadi Rp. 6. 400.000 (enam juta empat ratus ribu rupiah).

d. Dengan demikian, uang yang diterima pekerja/buruh pada saat PHK karena pensiun tersebut adalah Rp. 3.600.000,- (tiga juta enam ratus ribu rupiah), sebagai santunan dari penyelenggara program pensiun yang preminya $60 \%$ dibayar oleh pengusaha) ditambah Rp. 6.400.000,- (enam juta empat ratus ribu rupiah), yang berasal dari kekurangan pesangon yang harus dibayar oleh pengusaha, ditambah Rp. 2. 400.000,-(dua juta empat ratus ribu rupiah)yang merupakan santunan dari penyelenggara program pensiun yang preminya 40\% dibayar oleh buruh/pekerja, sehingga keseluruhan berjumlah Rp. 12.400.000,- (dua belas juta empatratus ribu rupiah).

Dengan demikian persoalan dari perbedaan perhitungan uang pesangon dan jaminan pensiun ini dari awal lebih disebabkan perspektif yang berbeda dalam menerjemahkan makna dari Pasal 167 ayat (1) (2) dan (3) UU Ketenagakerjaan. Sejak awal ketidakkonsistenan pengaturan uang pesangon di perusahaan yang sudah menyelenggarakan program jaminan pensiun diyakini akan menimbulkan persoalan dalam praktek. Semangat uang pesangon menjadi tergerus dengan kehadiran program jaminan pensiun. Mempersamakan uang pesangon dengan jaminan pensiun yang iurannya dibayarkan secara penuh oleh pengusaha berpotensi memunculkan konflik dalam hubungan industrial.

Dua SK Direksi yang menjadi kajian dalam penelitian ini telah menunjukkan hal tersebut. Akibat perbedaan persepsi tersebut yang berujung pada perbedaan perhitungan uang pesangon dan jaminan pensiun yang harus diterima pekerja, telah membawa pekerja dan pengusaha sampai pada tahap penyelesaian perselisihan secara mediasi. Sebelumnya penyelesaian secara bipartit tidak berhasil menyelesaikan persoalan tersebut.

Sebetulnya tidak terlalu sulit untuk mengetahui perhitungan yang benar dan salah. Satu indikator yang sederhana adalah uang pensiun yang diterima pekerja tidak boleh lebih rendah 


\section{KERTHA PATRIKA}

Volume 38, Nomor 1, Januari-April 2016

dari perhitungan uang pesangon normal jika premi dibayar penuh oleh pengusaha. Untuk yang preminya dibayar bersama antara pekerja dan pengusaha, jumlah pensiun yang diterima, selain melihat perhitungan besaran premi yang dibayarkan pengusaha, masih memperhitungkan santunan yang jumlahnya bergantung besaran premi yang dibayar pekerja serta selisih kekurangan yang masih harus dibayar pengusaha.

Dalam kasus yang diteliti di P.T. "X' dan "Y" tersebut, ${ }^{14}$ kedua perusahaan hanya memperhitungkan uang pesangon sebagai selisih antara kewajiban yang harus dibayar pengusaha atas uang pesangon dan jaminan pensiun yang preminya dibayar oleh pengusaha. Menurut perusahaan selisih tersebut sudah lebih besar dari pesangon yang seharusnya diterima pekerja, sehingga kepada pekerja tidak lagi perlu diberikan uang pesangon. Pekerja berpendapat bahwa besaran pensiun dilihat dari pesangon tidak cukup dilihat dari selisihnya saja. Selisih pesangon dan jaminan pensiun yang preminya dibayar pengusaha hanya salah satu unsur saja.

Dengan demikian wajar jika perhitungan uang pesangon versi pekerja berbeda jauh dengan versi pengusaha, karena parameternya berbeda. Itu sebabnya terjadi perdebatan yang cukup panjang dari kasus tersebut. Kasus tersebut sudah sampai di Dinas Ketenagakerjaan dan Transmigrasi (Disnakertrans) Provinsi Daerah Istimewa Yogyakarta, tetapi belum final, bahkan karena kedua perusahaan berupa Badan Usaha Milik Negara (BUMN), dan penyelesaiannya sampai saat ini masih di Jakarta. Isu ini termasuk memiliki sensitivitas tinggi dan saat ini sedang menjadi perhatian publik ketenagakerjaan bukan hanya di Yogyakarta, tetapi juga di Indonesia. Bahkan ada keinginan pengurus serikat buruh P.T. " $X$ " untuk mengajukan uji materiil keberadaan Pasal 167 UU Ketenagakerjaan ke Mahkamah Konstitusi karena dianggap sebagai sumber persoalan tersebut.

2. Keberadaan SK Direksi sebagai Dasar Hukum Pengaturan Uang Pesangon di Perusahaan yang Sudah Menyelenggarakan Program Jaminan Pensiun dari Perspektif Hukum Perburuhan

P.T. "X" dan "Y" yang menjadi kajian dalam penelitian ini, telah mengeluarkan SK Direksi, yang mengatur tentang "penyelesaian kewajiban perusahaan terhadap pekerja yang berakhir hubungan kerjanya karena mencapai usia pensiun normal" dan "Penetapan Manfaat Pensiun". SK Direksi tersebut telah menimbulkan permasalahan karena mengakibatkan lebih dari 50\% para pensiunan PT "X" dan "Y" tersebut tidak menerima pensiun sama sekali.

Dalam SK Direksi di dua perusahaan tersebut, iuran pensiun yang merupakan beban perusahaan diperhitungkan sebagai pembanding uang pesangon, dengan ketentuan apabila dalam pembayaran iuran pensiun oleh perusahaan terdapat kelebihan atau sama dengan uang pesangon maka perusahaan tidak akan memberikan pesangon, tetapi jika iuran pensiun dari perusahaan lebih kecil setelah dibandingkan dengan uang pesangon, maka perusahaan akan membayarkan kekurangannya dan dianggap sebagai pesangon. Konsep tersebut dianggap pengusaha sudah mengimplementasikan amanah UU Ketenagakerjaan mengenai keberadaan uang pesangon di perusahaan yang menyelenggarakan jaminan pensiun dan menyamakan uang pesangon dengan jaminan pensiun yang preminya dibayar penuh oleh pengusaha.

\footnotetext{
${ }^{14}$ Data kedua perusahaan ada di Penulis
} 
Dalam UU Ketenagakerjaan, dalam hal pengusaha telah mengikutsertakan pekerja/buruh dalam program pensiun yang iurannya/preminya dibayar oleh pengusaha dan buruh/pekerja, maka yang diperhitungkan sebagai pesangon adalah uang pensiun yang preminya dibayar oleh pengusaha. Dengan demikian kehadiran SK Direksi tersebut oleh perusahaan dianggap sebagai implementasi dari UU Ketenagakerjaan untuk mengatur keberadaan uang pesangon karena dalam perusahaan tersebut sudah menyelenggarakan program jaminan pensiun.Hal tersebut berangkat dari sebuah pemikiran bahwa UU Ketenagakerjaan telah memberi dasar kepada perusahaan yang telah menyelenggarakan program jaminan pensiun untuk mengatur mengenai keberadaaan uang pesangon dalam perjanjian kerja, peraturan perusahaan, atau perjanjian kerja bersama. Dalam hal ini SK Direksi menurut perusahaan dipersamakan dengan peraturan perusahaan.

SK Direksi dianggap sebagai aturan internal perusahaan yang mengikat buruh/pekerja untuk mengikutinya. SK Direksi yang dipolakan dari atas dianggap mewakili karakter peraturan perusahaan sehingga tidak memerlukan persetujuan buruh dalam pembuatannya. Artinya, tidak ada pilihan lain bagi buruh untuk menerima kehadiran SK Direksi tersebut.

Sebenarnya tidak ada yang istimewa dalam formulasi SK Direksi tersebut. Persoalan muncul karena setelah SK tersebut diimplementasikan, ternyata cara perhitungannya berbeda yang membawa hasil perhitungan yang berbeda pula. Perbedaan tersebut disebabkan karena perspektif yang berbeda dalam memaknai ketentuan UU Ketenagakerjaan yang mengatur mengenai keberadaan uang pesangon di perusahaan yang sudah menyelenggarakan program jaminan pensiun.

Menurut UU Ketenagakerjaan, pengusaha dapat melakukan pemutusan hubungan kerja terhadap buruh karena memasuki usia pensiun dan apabila pengusaha telah mengikutkan buruh dalam program jaminan pensiun yang iurannya dibayar penuh oleh pengusaha, maka buruh tidak berhak mendapatkan pesangon dan uang penghargaan masa kerja. Dalam hal ini buruh tetap berhak uang penggantian hak.

Dalam hal besarnya jaminan atau manfaat pensiun yang diterima sekaligus dalam program pensiun ternyata lebih kecil dari ketentuan mengenai uang pesangon dan penghargaan masa kerja serta penggantian hak, maka selisihnya dibayar oleh pengusaha. Dalam hal pengusaha telah mengikutsertakan buruh dalam program pensiun yang iuran/preminya dibayar oleh pengusaha dan buruh, maka yang diperhitungkan sebagai uang pesangon adalah uang pensiun yang premi/ iurannya dibayar oleh pengusaha.

Ketentuan dalam UU Ketenagakerjaan dapat diatur lain dalam perjanjian kerja, peraturan perusahaan atau perjanjian kerja bersama. Hal inilah salah satunya yang membuat beberapa perusahaan mengatur mengenai keberadaan uang pesangon dan jaminan pensiun dalam aturan internal perusahaan, termasuk dalam bentuk SK Direksi. Ketentuan tersebut juga menyiratkan karakter privat dari hukum perburuhan yang memberi peluang bagi para pihak untuk mengatur sendiri hubungan di antara mereka dalam berbagai hal tertentu. Hanya saja, ketentuan tentang peluang pengaturan dalam bentuk perjanjian kerja, peraturan perusahaan atau perjanjian kerja bersama tersebut yang pada akhirnya menimbulkan persoalan, seperti misalnya kehadiran SK Direksi untuk mengatur hal tersebut.

Perusahaan yang dijadikan kajian dalam penelitian ini merupakan BUMN, sehingga Direksi dari PT tersebut adalah pejabat negara. Segala keputusan Direksi, yang diterbitkan dalam bentuk 


\section{KERTHA PATRIKA}

Volume 38, Nomor 1, Januari-April 2016

tertulis, sebagai suatu keputusan yang tertulis, atau sebagai penetapan tertulis merupakan salah satu bentuk dari Keputusan Badan atau Pejabat Tata Usaha Negara.

Untuk dapat mencermati Keputusan Tata Usaha Negara terlebih dahulu harus dilihat penafsiran otentiknya. Pengertian Keputusan Tata Usaha Negara menurut Pasal 1 angka 9 Undang-Undang Nomor 5 tahun 1986 tentang Peradilan Tata Usaha Negara, sebagaimana telah diubah dengan Undang-Undang Nomor 9 tahun 2004 dan akhirnya diubah lagi dengan Undang-Undang Nomor 51 tahun 2009 adalah suatu penetapan tertulis yang diterbitkan oleh Badan atau Pejabat Tata Usaha Negara yang berisi tindakan hukum tata usaha negara yang berdasarkan peraturan perundangan yang berlaku, yang bersifat konkrit, individual dan final, yang menimbulkan akibat hukum bagi seseorang atau badan hukum perdata.

Dari penjelasan undang-undang tersebut, ditentukan bahwa dikatakan bersifat konkret artinya subyek yang diatur dalam keputusan tersebut harus berwujud, tertentu atau dapat ditentukan. Bersifat individual artinya bahwa Keputusan Tata Usaha Negara tidak ditujukan untuk umum, tetapi tertentu, baik alamat atau personel maupun hal yang dituju, sehingga apabila yang dituju lebih dari seorang, maka tiap-tiap nama orang yang terkena keputusan tersebut, harus disebutkan namanya. Final artinya sudah definitif dan karenanya dapat menimbulkan akibat hukum atau menimbulkan hak dan kewajiban bagi para pihak yang bersangkutan. Keputusan yang masih memerlukan persetujuan dari instansi atasan atau instansi lain belum bersifat final.

Tidak semua keputusan dari pejabat Tata Usaha Negara dapat dikatagorikan sebagai Keputusan Tata Usaha Negara. Dianggap sebagai bukan Keputusan Tata Usaha Negara seperti misalnya keputusan Tata Usaha Negara yang merupakan perbuatan hukum perdata, merupakan pengaturan yang bersifat umum, masih memerlukan persetujuan, dikeluarkan berdasarkan Kitab Undang-Undang Hukum Pidana (KUHP) dan Kitab Undang-Undang Hukum Acara Pidana (KUHAP) ataupun peraturan yang bersifat pidana, diterbitkan atas dasar hasil pemeriksaan badan peradilan, mengenai Tata Usaha Tentara Nasional Indonesia dan keputusan Komisi Pemilihan Umum (KPU) baik di pusat maupun daerah mengenai hasil pemilihan umum.

SK Direksi yang menjadi kajian penelitian ini mengatur hal-hal yang bersifat umum, yaitu tentang penyelesaian kewajiban perusahaan terhadap pekerja yang berakhir hubungan kerjanya karena mencapai usia pensiun dan penetapan manfaat pensiun. Karena mengatur hal-hal yang bersifat umum, maka SK Direksi tersebut bukan Keputusan Tata Usaha Negara tetapi merupakan aturan internal perusahaan.

Dalam UU Ketenagakerjaan segala aturan yang diterbitkan oleh perusahaan maupun hasil kesepakatan buruh dan pengusaha tidak boleh bertentangan dengan peraturan perundangan yang berlaku. Ini adalah salah satu bentuk pembatasan asas kebebasan berkontrak. Bahkan, UU Ketenagakerjaan sudah menentukan bentuk dan isi dari peraturan perusahaan, perjanjian kerja dan perjanjian kerja bersama. Dengan demikian, maka SK Direksi sebagai aturan perusahaan tidak boleh bertentangan dengan peraturan perundangan. Dalam hal aturan perusahaan bertentangan dengan peraturan perundangan maka aturan perusahan tersebut batal demi hukum.

Persoalan yang muncul adalah apakah dalam peraturan perundangan-undangan sudah diatur mengenai peraturan perusahaan dan bagaimana sifat pengaturan peraturan perusahaan tersebut dalam UU Ketenagakerjaan. Hal ini disebabkan karena peraturan perusahaan yang diatur dalam UU Ketenagakerjaan bisa berbeda dengan karakter SK Direksi yang diterbitkan oleh BUMN. Hal lain 
yang juga perlu diberi perhatian adalah karakter pengaturan mengenai peraturan perusahaan yang bersifat memaksa karena sifat publik hukum perburuhan.

Peraturan perusahaan menurut UU Ketenagakerjaan adalah peraturan yang dibuat oleh pengusaha secara tertulis yang memuat syarat-syarat kerja dan tata tertib perusahaan. Peraturan Perusahaan disusun oleh dan menjadi tanggung jawab pengusaha yang bersangkutan. Peraturan Perusahaan disusun dengan memperhatikan saran dan pertimbangan dari wakil buruh yang bersangkutan. Peraturan perusahaan wajib dimiliki oleh perusahaan yang mempekerjakan buruh sekurang-kurangnya sepuluh orang.

Peraturan Perusahaan sekurang-kurangnya memuat hak dan kewajiban pengusaha dan buruh, syarat kerja, tata tertib perusahaan dan jangka waktu berlakunya peraturan perusahaan. Ketentuan dalam peraturan perusahaan tidak boleh bertentangan dengan peraturan perundangan. Masa berlaku peraturan perusahaan paling lama dua tahun dan wajib diperbaharui setelah habis masa berlakunya, dengan ancaman sanksi pidana denda minimal lima juta rupiah dan setinggitingginya lima puluh juta rupiah atas pelanggarannya. Peraturan perusahaan disahkan oleh menteri atau pejabat yang ditunjuk. Perubahan peraturan perusahaan sebelum berakhir jangka waktu berlakunya hanya dapat dilakukan atas dasar kesepakatan antara pengusaha dan wakil buruh.

Menurut Pasal 114 UU Ketenagakerjaan, Pengusaha wajib memberitahukan dan menjelaskan isi serta memberikan naskah peraturan perusahaan atau perubahannya kepada buruh. Pengusaha yang tidak memenuhi kewajiban tersebut, berdasarkan Pasal 188 UU Ketenagakerjaan diancam dengan sanksi pidana denda paling sedikit lima juta rupiah dan paling banyak lima puluh juta rupiah. Tindak pidana tersebut merupakan tindak pidana pelanggaran.

UU Ketenagakerjaan memberikan kesempatan kepada pengusaha dan buruh untuk mengatur lain mengenai keberadaan uang pesangon di perusahaan yang sudah menyelenggarakan program jaminan pensiun. Pengaturan tersebut bisa dalam bentuk perjanjian kerja, peraturan perusahaan atau perjanjian kerja bersama.

Jika dilihat dari cara pembentukan, isi maupun sifat peraturan perusahaan tersebut maka SK Direksi tersebut bukan peraturan perusahaan seperti yang dimaksud dalam UU Ketenagakerjaan, sehingga tidak dapat dijadikan sebagai dasar hukum pengaturan pesangon di perusahaan yang sudah menyelenggarakan program jaminan pensiun. Ketentuan mengenai peraturan perusahaan yang ada di dalam UU Ketenagakerjaan bersifat pemaksa, bukan pelengkap. Sifat pemaksa ketentuan mengenai peraturan perusahaan meliputi pengaturan proses, isi dan bentuk peraturan perusahaan. Artinya pengusaha yang menyelenggarakan program jaminan pensiun tidak dapat mengatur uang pesangon bertentangan dengan hukum yang bersifat pemaksa. Apalagi, menurut UU Ketenagakerjaan ada implikasi yuridis atas pelanggaran aturan tersebut.

\section{Kesimpulan dan Saran}

\section{Kesimpulan}

a. Keberadaan uang pesangon di perusahaan yang sudah menyelenggarakan program jaminan pensiun dipersamakan dengan jaminan pensiun yang premi atau iurannya dibayar penuh oleh pengusaha dengan catatan jaminan pensiun tidak lebih rendah dari besaran pesangon karena pensiun yang seharusnya diterima oleh buruh. Dengan demikian kehadiran program 


\section{KERTHA PATRIKA}

Volume 38, Nomor 1, Januari-April 2016

jaminan pensiun tidak otomatis dapat meniadakan uang pesangon yang seharusnya diterima oleh buruh ketika memasuki usia pensiun. UU Ketenagakerjaan tidak konsisten dalam pengaturan mengenai uang pesangon dan jaminan pensiun karena awalnya pesangon dan jaminan pensiun diatur dalam pengaturan yang berbeda sebab memang merupakan dua hal yang memiliki karakter berbeda.

b. SK Direksi dari perspektif Hukum Perburuhan tidak dapat dijadikan dasar hukum pengaturan uang pesangon di perusahaan yang sudah menyelenggarakan program jaminan pensiun karena bukan peraturan perusahaan seperti yang dimaksudkan dalam UU Ketenagakerjaan, baik dilihat dari proses, sifat maupun isinya. Ketentuan Peraturan Perusahaan dalam UU Ketenagakerjaan bersifat pemaksa dan tidak dapat disimpangi, sehingga tidak dapat dipersamakan dengan SK Direksi.

\section{Saran}

a. Kepada pembuat kebijakan, pengaturan uang pesangon di perusahaan yang menyelenggarakan program jaminan pensiun sebaiknya dipertegas agar tidak menimbulkan penafsiran yang berbeda dari pelaku hubungan industrial. Pengaturan sebaiknya tidak bertentangan dengan roh atau semangat keberadaan uang pesangon dan jaminan pensiun.

b. Kepada pengusaha, pengaturan mengenai uang pesangon jika sudah menyelenggarakan jaminan pensiun sebaiknya tidak dalam bentuk SK Direksi tetapi dalam bentuk perjanjian kerja, peraturan perusahaan atau perjanjian kerja sebagaimana ditentukan di dalam UU Ketenagakerjaan.

c. Kepada buruh di perusahaan yang sudah memiliki serikat buruh, sebaiknya mengajukan permohonan kepada pengusaha agar pengaturan uang pesangon dan jaminan pensiun ditingkatkan dalam bentuk perjanjian kerja bersama yang lebih tinggi tingkatannya dari perjanjian kerja dan peraturan perusahaan

\section{DAFTAR PUSTAKA}

\section{A. Buku}

Arfianto, Alex. 2004. Perbaikan Sistem Jaminan Sosial di Indonesia, Sebuah Analisis tentang RUU Jaminan Sosial Nasional,Ringkasan Eksekutif Penelitian, SMERU Research Institute, Jakarta.

Damanik, Sehat.2007. Hukum Acara Perburuhan, Dss Publishing, Jakarta.

Habibi, Muhtar. 2009. Gemuruh Buruh Di Tengah Pusaran Neoliberalisme : Pengadopsian Kebijakan Perburuhan Neoliberal Pasca Orde Baru, Gava Media, Yogyakarta.

Husni, Lalu. 2005. Penyelesaian Perselisihan Hubungan Industrial Melalui Pengadilan dan di Luar Pengadilan, RajaGrafindo Persada, Jakarta.

16 | Jurnal Ilmiah Fakultas Hukum Universitas Udayana 
Keberadaan Uang Pesangon Dalam Pemutusan Hubungan Kerja Demi Hukum di Perusahaan yang Sudah Menyelenggarakan Program Jaminan Pensiun

Ari Hernawan

Ihrom, Tapi Omas. 2006. "Sistem Jaminan Sosial Indonesia dalam Perubahan", Artikel dalam Buku Makin Terang Bagi Kami Belajar Hukum Perburuhan, TURC, Jakarta.

Michael, Raper. 2008. Negara Tanpa Jaminan Sosial, TURC, Jakarta,

Sedarmayanti. 2011. Manajemen Sumber Daya Manusia, Refika Aditama, Bandung.

Tjandra, Surya, Hanggrahini, Rani. 2007. Hukum Perburuhan, Desentralisasi dan Rekonstitusi Rezim Perburuhan, TURC, Jakarta.

Warman, Muhammad Aditya. 2013. Social Security and Minimum Wages in Indonesia, Pusat Studi Apindo, Jakarta.

\section{B. Jurnal/Makalah}

International Labour Organization. 2002. "Social Security and Coverage for all”, Paper in International Labour Office, Jakarta.

Roni Febrianto, “Jaminan Sosial, Haruskah Rakyat Menunggu?”, Jurnal Kajian Perburuhan SEDANE, 2001, Vol. 11, No. 1.

\section{Peraturan Perundang-undangan}

Undang-Undang Nomor 11 Tahun 1992 Tentang Dana Pensiun (Lembaran Negara Republik Indonesia Tahun 1992 Nomor 37, Tambahan Lembaran Negara Republik Indonesia Nomor 3477)

Undang-Undang Nomor 43 Tahun 1999 Tentang Perubahan atas Undang-Undang Nomor 8 Tahun 1974 tentang Pokok-Pokok Kepegawaian (Lembaran Negara Republik Indonesia Tahun 1999 Nomor 169, Tambahan Lembaran Negara Republik Indonesia Nomor 3890)

Undang-Undang Nomor 21 Tahun 2000 Tentang Serikat Pekerja (Lembaran Negara Republik Indonesia Tahun 2000 Nomor 131, Tambahan Lembaran Negara Republik Indonesia Nomor 3989)

Undang-Undang Nomor 13 Tahun 2003 Tentang Ketenagakerjaan (Lembaran Negara Republik Indonesia Tahun 2003 Nomor 39, Tambahan Lembaran Negara Republik Indonesia Nomor 4279)

Undang-Undang Nomor 2 Tahun 2004 Tentang Penyelesaian Perselisihan Hubungan Industrial (Lembaran Negara Republik Indonesia Tahun 2004 Nomor 6, Tambahan Lembaran Negara Republik Indonesia Nomor 4356)

Undang-Undang Nomor 40 Tahun 2004 Tentang Sistem Jaminan Sosial Nasional (Lembaran Negara Republik Indonesia Tahun 2004 Nomor 150, Tambahan Lembaran Negara Republik Indonesia Nomor 4456)

Undang-Undang Nomor 51 Tahun 2009 Tentang Perubahan Kedua atas Undang-Undang Nomor 5 Tahun 2006 tentang Peradilan Tata Usaha Negara (Lembaran Negara Republik Indonesia Tahun 2009 Nomor 160, Tambahan Lembaran Negara Republik Indonesia Nomor 5079) 